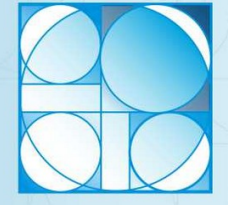

Inovações educacionais
Journal of Biochemistry Education

Revista de Ensino de Bioquímica

Revista de Enseñanza de Bioquímica

64 Sociedade Brasileira de Bioquimica
V. 19, N.1 / 2021

Submitted in: 2 mar 2020 Published in: 15 jul 2021

\title{
PHYSIOLOGY TEACHING IN THE PBL (PROBLEM-BASED LEARNING) CONTEXT: REPORT OF WORKSHOPS DEVELOPED IN BRAZIL
}

\section{ENSINO DE FISIOLOGIA NO CONTEXTO PBL (APRENDIZAGEM BASEADA EM PROBLEMAS): RELATÓRIO DE OFICINAS DESENVOLVIDAS NO BRASIL}

Lidiane Dal Bosco ${ }^{1 *}$, Bem-Hur Souto das Neves; Pâmela Billig Mello-Carpes ${ }^{1 *}$

${ }^{1}$ Physiology Research Group. University Federal of Pampa. Uruguaiana, RS, Brazil

*e-mail: pamelacarpes@unipampa.edu.r

\begin{abstract}
The workshop entitled "Physiology teaching in the Problem-based learning (PBL) context" was developed in two different times and contexts in Brazil, during 2017 and 2018. The main goal was to show how PBL works and discuss different possibilities and strategies to include physiology education in this different context of nontraditional teaching, where the role of professor changes. The workshop was highly valuable, gave an initial basis on PBL to the participants and stimulates them to think about the possibilities of PBL use and the potentials of this method, in both contexts of application.
\end{abstract}

Keywords: Physiology education; active learning; Problem-based learning; teachers' training.

\section{Resumo}

O workshop intitulado "Ensino de fisiologia no contexto da aprendizagem baseada em problemas (ABP)" foi desenvolvido em dois momentos e contextos diferentes no Brasil, durante 2017 e 2018. O principal objetivo era mostrar como o ABP funciona e discutir diferentes possibilidades e estratégias para incluir ensino de fisiologia neste diferente contexto do ensino não tradicional, no qual o papel do professor muda. O workshop foi altamente valioso, deu uma base inicial ao ABP para os participantes e os estimulou a pensar sobre as possibilidades de uso do $A B P$ e as potencialidades desse método, nos dois contextos de aplicação.

Palavras-chave: Educação em fisiologia; aprendizagem ativa; aprendizagem baseada em problemas; formação de professores. 


\section{Introduction}

The workshop entitled "Physiology teaching in the PBL (Problem-based learning) context" was developed in two different times and contexts. The first edition of the workshop was organized and developed with Physiology master's and PhD students in 2017, in Uruguaiana/RS, Brazil. The second edition was adapted and developed in 2018, during the IV Physiology Teaching Workshop organized by Educational Committee of Brazilian Physiological Society, whose participants were Physiology professors, master's and PhD students, in Araraquara/SP, Brazil.

The main goal of the workshop was to show how PBL works and discuss different possibilities and strategies to include physiology education in the context of non-traditional teaching. The workshop proposal was supported by the previous experience of the facilitators in promoting this strategy for teaching in the recent years. In the first edition of the workshop, fifteen Physiology master's or PhD students from Multicentric Graduate Program in Physiological Sciences of Federal University of Pampa and Brazilian Physiological Society, who were enrolled in a Physiology Teaching course, participated. In the second edition of workshop, forty-nine people acting or intending to act in Physiology Education, who were enrolled in the Annual Brazilian Physiology Teaching Workshop, participated. All the participants were Brazilian.

PBL has been introduced as an innovative educational approach in many undergraduate courses all over the world. This instructional method was initially proposed in undergraduate medical education aimed to develop reasoning skills based on clinical problems. McMaster University School of Medicine was the first to implement PBL in their medical curriculum in 1968 (1). The basis of PBL is the active learning in small collaborative groups in which a problem is discussed by students under the guidance of a tutor $(2,3)$. In this context, learning occurs by the activation of prior knowledge and integration of new information, which allows students to synthesize knowledge from different domains and apply them to solve problems $(1,4)$.

Teachers in PBL assume vital roles for the effectiveness of the learning experience. As tutors, they facilitate the learning process in tutorial sessions by guiding students to develop problem solving skills and motivating them to construct their knowledge (4). As curriculum designers, they should determine the way to organize the contents of the course and how issues could be developed through PBL (2). Throughout the entire PBL process, teachers play the role of evaluators, monitoring the effectiveness of the tutorial process and the students' performances (2).

The methodology and application of PBL vary considerably. While some courses 
and institutions implement single or multiple PBL interventions within the traditional curriculum framework, others adopt PBL as a whole-curriculum concept (3). Despite this diversity, there are three characteristics that should be considered as essential: problems as a stimulus for learning, teachers as facilitators of the learning process and group work as a stimulus for interaction.

In Brazil, the School of Medicine in Marília and the State University of Londrina were the first to implement a curriculum completely based on PBL in the late 90's $(5,6)$. More recently, the emergence of Brazilian undergraduate courses that adopted PBL increased as a consequence of programs and guidelines of the Ministries of Education and Health that strongly encourage the use of active learning approaches and curriculum innovation in health professions education (7). Although important curricular reforms were carried out in the last few years, especially in Brazilian medical schools, there are still many challenges to be overcome for the implementation of the student-centered methodologies. The curricular changes for PBL implementation, especially from a traditional curriculum, requires availability of resources and institutional efforts primarily for faculty development and training, development of the curriculum and its policies, and preparation of the students $(6,7)$.

These challenges are even greater in Brazil, where teachers assume the role of lecturers rather than students' tutors (8), and there is still a lack of pedagogical training for future professors (9). In this scenario, physiology is taught by different teaching methods, including traditional lecture classes, PBL, case-based learning, or by a combination of teaching strategies, commonly without any pedagogical training. Considering the relevance of physiology learning for health professionals and the growing number of undergraduate courses that have adopted a PBL-oriented curriculum, the development of teaching skills is an important issue for physiology teachers' formation and permanent education. Here we will describe two different initiatives of teachers' training that aimed to introduce the principles of PBL and offered an opportunity to experience the PBL steps.

\section{Workshop with Physiology master's or PhD students}

This workshop was developed with fifteen Physiology master's or PhD students from Multicentric Graduate Program in Physiological Sciences of Federal University of Pampa, enrolled in an optional Physiology Teaching course in June 2017 in Uruguaiana/RS/Brazil. The activities of the workshop were developed in two days, separated by one week from each other. Table 1 illustrates the stages of the workshop. 
Table 1. Stages of the workshop developed with Physiology master's and PhD students.

\begin{tabular}{|c|c|c|c|}
\hline Day & Stage & Main objective & Methods \\
\hline 1 & Introduction to $\mathrm{PBL}$ & $\begin{array}{l}\text { To introduce the } \\
\text { principles and main } \\
\text { characteristics of PBL. }\end{array}$ & $\begin{array}{l}\text { Oral presentation and discussion about } \\
\text { the PBL method. }\end{array}$ \\
\hline 1 & Opening session & $\begin{array}{l}\text { To experience the first } \\
\text { stage of the PBL } \\
\text { process. }\end{array}$ & $\begin{array}{l}\text { A problem was presented in a printed text. } \\
\text { Students discussed the problem, } \\
\text { generating hypotheses and explanations } \\
\text { based on their previous experience or } \\
\text { knowledge. From the identification of } \\
\text { knowledge gaps, they formulated learning } \\
\text { objectives based on topics they } \\
\text { considered useful for clarifying and solving } \\
\text { the problem. }\end{array}$ \\
\hline $\begin{array}{l}2-7 \\
\text { (non- } \\
\text { presential } \\
\text { activity) }\end{array}$ & Self-directed learning & $\begin{array}{l}\text { To experience the } \\
\text { second stage of } \mathrm{PBL} \\
\text { (self-directed } \\
\text { learning). }\end{array}$ & $\begin{array}{l}\text { From the learning objectives defined in the } \\
\text { first tutorial, the students worked } \\
\text { independently, searching information and } \\
\text { studying the topics. }\end{array}$ \\
\hline 8 & Closing session & $\begin{array}{l}\text { To experience the last } \\
\text { stage of PBL. }\end{array}$ & $\begin{array}{l}\text { Students shared what they learned } \\
\text { through discussions and applied them to } \\
\text { the problem scenario. }\end{array}$ \\
\hline 8 & Final remarks & $\begin{array}{l}\text { To discuss the PBL } \\
\text { experience as } \\
\text { students and other } \\
\text { topics related to the } \\
\text { tutor's role. }\end{array}$ & $\begin{array}{l}\text { Students were stimulated to share their } \\
\text { impressions about the PBL experience. } \\
\text { Afterward they discussed the role of } \\
\text { professors as tutors, as well as the } \\
\text { students' evaluation and problem design } \\
\text { in PBL. }\end{array}$ \\
\hline
\end{tabular}

Workshop developed during the IV Physiology Teaching Workshop organized by Educational Committee of Brazilian Physiological Society

The second workshop was developed with forty-nine people acting or intending to act in Physiology Education (Physiology professors, master's and PhD students) and enrolled in the Annual Brazilian Physiology Teaching Workshop in July 2018 in Araraquara/ SP/Brazil. This workshop was adapted to one-day practice. Table 2 illustrates the stages of the workshop. 
Table 2. Stages of the workshop developed during the IV Physiology Teaching Workshop organized by Educational Committee of Brazilian Physiological Society.

\begin{tabular}{l|l|l}
\hline \multicolumn{1}{c|}{ Stage } & \multicolumn{1}{|c}{ Main objective } & \multicolumn{1}{c}{ Methods } \\
\hline Introduction to PBL & $\begin{array}{l}\text { To introduce the } \\
\text { principles and main } \\
\text { characteristics of PBL. }\end{array}$ & $\begin{array}{l}\text { Oral presentation and discussion about the PBL } \\
\text { method. }\end{array}$ \\
\hline Opening session & $\begin{array}{l}\text { To start a PBL practice } \\
\text { and experience. }\end{array}$ & $\begin{array}{l}\text { A problem scenario was presented in a printed text. } \\
\text { Students discussed the problem, generating } \\
\text { hypotheses and explanations based on their previous } \\
\text { experience or knowledge. From the identification of } \\
\text { knowledge gaps, they formulated learning objectives } \\
\text { based on topics they considered useful for clarifying } \\
\text { and solving the problem. }\end{array}$ \\
\hline $\begin{array}{l}\text { Presentation about } \\
\text { the next PBL stages } \\
\text { (self-directed }\end{array}$ & $\begin{array}{l}\text { To present and discuss } \\
\text { the next stages of PBL. }\end{array}$ & $\begin{array}{l}\text { The next stages of PBL (self-directed learning and } \\
\text { learning and closing tutorial session) were presented and } \\
\text { discussed. Aspects of their implementation } \\
\text { session) }\end{array}$ \\
\hline Final remarks & $\begin{array}{l}\text { To discuss the PBL } \\
\text { experience as students } \\
\text { and other topics related } \\
\text { to the tutor's role. }\end{array}$ & $\begin{array}{l}\text { Participants were stimulated to share their impressions } \\
\text { about the PBL experience. Afterward they discuss the } \\
\text { role of professors as tutors, as well as students' } \\
\text { evaluation and problem design in PBL. }\end{array}$ \\
\hline
\end{tabular}

After the workshops, we contacted the participants by e-mail and sent a questionnaire asking for their evaluation of the workshops. Twenty participants, 10 from the first workshop and 10 from the second, answered the questionnaire. The respondents were between 23 and 56 years old (55\%, $n=11,23-30$ years-old, $25 \%, n=5,31-41$ years-old, $20 \%, n=4,42-56$ years-old), consisting of $60 \%$ female $(n=12)$ and $40 \%$ male $(n=8)$.

We asked the participants if they already knew about the PBL method before the workshop. Fifteen participants (75\%) had heard and/or read about PBL (some of them had participated in lectures about PBL or knew colleagues that work using this method), $20 \%$ $(n=4)$ said that it was their first contact with PBL, and $5 \%(n=1)$ affirmed that they already used PBL in teaching. Therefore, the PBL practice was a novelty for most of the participants.

To evaluate the workshop and the perception of participants about PBL after the 
workshop, we used a Likert scale to present several statements to the participants and asked about their level of agreement with each. The results are demonstrated in table 3.

Table 3. Participants' opinion about the workshop fulfilled. The data is presented as percentage (absolute number).

\begin{tabular}{|c|c|c|c|c|c|}
\hline Affirmation/level of agreement & $\begin{array}{l}\text { Fully } \\
\text { agree }\end{array}$ & $\begin{array}{l}\text { Partially } \\
\text { agree }\end{array}$ & $\begin{array}{c}\text { Do not } \\
\text { agree or } \\
\text { disagree }\end{array}$ & $\begin{array}{l}\text { Partially } \\
\text { disagree }\end{array}$ & $\begin{array}{c}\text { Fully } \\
\text { disagree }\end{array}$ \\
\hline $\begin{array}{l}\text { The workshop met my } \\
\text { expectations. }\end{array}$ & $60 \%(12)$ & $40 \%(8)$ & 0 & 0 & 0 \\
\hline $\begin{array}{l}\text { The workshop was enough for me } \\
\text { to understand the stages and the } \\
\text { tutorial process of PBL. }\end{array}$ & $35 \%(7)$ & $55 \%(11)$ & $5 \%(1)$ & $5 \%(1)$ & 0 \\
\hline $\begin{array}{l}\text { The use of the PBL method can } \\
\text { contribute to a better learning of } \\
\text { physiology. }\end{array}$ & $75 \%(15)$ & $20 \%(4)$ & $5 \%(1)$ & 0 & 0 \\
\hline $\begin{array}{l}\text { The workshop allowed me to } \\
\text { understand how the teaching of } \\
\text { physiology is developed in the } \\
\text { context of PBL. }\end{array}$ & $70 \%(14)$ & $30 \%(6)$ & 0 & 0 & 0 \\
\hline $\begin{array}{l}\text { The integration of physiology with } \\
\text { other areas of knowledge is } \\
\text { favored with the use of the PBL } \\
\text { method. }\end{array}$ & $95 \%(19)$ & $5 \%(1)$ & 0 & 0 & 0 \\
\hline $\begin{array}{l}\text { Before the workshop, I already } \\
\text { visualized myself as a professor } \\
\text { using } \mathrm{PBL} \text { as a teaching strategy. }\end{array}$ & $15 \%(3)$ & $30 \%(6)$ & $15 \%(3)$ & $20 \%(4)$ & $20 \%(4)$ \\
\hline $\begin{array}{l}\text { After the workshop, I started to see } \\
\text { the possibility of using PBL as a } \\
\text { teaching strategy. }\end{array}$ & $45 \%(9)$ & $50 \%(10)$ & 0 & 0 & $5 \%(1)$ \\
\hline $\begin{array}{l}\text { I consider it important to discuss } \\
\text { PBL in the initial and continuing } \\
\text { training of future physiology } \\
\text { teachers. }\end{array}$ & $85 \%(17)$ & $15 \%(3)$ & 0 & 0 & 0 \\
\hline
\end{tabular}

Some of the participants added comments after the workshop evaluation, including on the importance of practicing the PBL method to understand how it works, the idea of having more time to discuss and practice the method, and the necessity of institutional 
adaptations of the physical and personnel infrastructure to have the possibility of using PBL. Many participants wrote comments that praised the workshop. In the end we also asked to them to attribute a grade to the workshop, considering a scale from 0 (very bad) to 10 (excellent): $45 \%(n=9)$ attributed grade 10 to the workshop, $25 \%(n=5)$ grade 9 , $25 \%(n=5)$ grade 8 , and $5 \%(n=1)$ grade 7 .

\section{Final comments}

The workshop was closed by some general comments by the facilitators and participants concerning the activities proposed. Some remarks include: the need of training teachers to implement the PBL method, the need of institutional and curricular adaptations, the need of changes in physical and personnel infrastructure to implement the PBL method, and the importance of discussing physiology education during the formation of future physiology professors among others. The general potentials and difficulties related to the method were also discussed. Among the potentials, the PBL promotion of a deep approach to learning was cited, which is reasoned by the literature (10). Among the difficulties to PBL implementation and acceptance, the lack of concrete reports evaluating the curricular outcomes was cited (11).

Considering the special competences that PBL requires, which many times were not developed during teachers' formation, faculty development is a crucial component of successful curriculum change to PBL (12). Faculty development interventions can promote improvements in teaching and continuous learning, encouraging teachers to innovate in their teaching strategies and creating an opportunity for collaboration and valorization of educational practice and research $(5,6,8)$. Workshops constitute a faculty developmental initiative commonly used to promote the acquisition of skills or to help faculty adapt to new teaching environments. These initiatives became popular because of their inherent flexibility and promotion of active learning (13).

Faculty development programs and workshops for training in PBL are not a novelty (14-16). However, it is important to highlight that in Brazil few higher education institutions promote effective faculty development programs (17). In addition, there are a small number of programs that offer teaching training for the future health professionals' educators, such as graduate students (18). Thus, many of these professionals who choose to become a teacher have learned to teach in practice, usually based on the educational models they have throughout their academic training (9).

In spite of the mentioned deficiencies, some initiatives in Brazil have been effective 
in promoting faculty training and development of health professions education. An example is the Faculty Development Program for Health Professions Educators of Brazil-FAIMER Regional Institute, a two-year faculty development program for health professions educators aiming to develop leadership in different scenarios of health professions' formation in Brazil (19). With ten years of duration, around 300 fellows completed the program, many of whom have carried out projects aimed to innovate teaching practices in the training of health professionals (20).

Other initiatives, more closely related to Physiology teaching, have been promoted by the Brazilian Physiological Society Educational Committee. A series of Physiology Teaching Workshops, focused on active teaching-learning methods and use of technology in classroom, were carried out in the last few years ${ }^{1}$. Members of the Brazilian Physiological Society Teaching Committee were also engaged in promoting workshops in active teaching methods during the 38th International Union of Physiological Sciences (IUPS) and ADInstruments Teaching Workshop held on 2017 in Brazil (21, 22). These initiatives have demonstrated to be important opportunities to share knowledge and experiences, as well as promoting reflection on teaching practice and building a professional network.

As a conclusion, considering our experiences as well as the comments, discussions and evaluations of the workshops described here, we believe that both of our initiatives, adapted to two different contexts and groups of participants were highly valuable, provided an initial basis on PBL to the participants and stimulated them to think about the possibilities of the use of this method in their educational and organizational settings. The relevance of the workshops for improving teaching physiology may encourage further initiatives. Additionally, the investigation on their effectiveness can improve pedagogical practice and physiology learning.

\section{References}

[1]. Taylor D, Miflin B. Problem-based learning: where are we now? Medical teacher. 2008;30(8):742-63.

[2]. Delisle R, Supervision Af, Development C. How to Use Problem-based Learning in the Classroom: ASCD; 1997.

[3]. Klegeris A, Hurren $\mathrm{H}$. Impact of problem-based learning in a large classroom setting: student perception and problem-solving skills. Adv Physiol Educ. 2011;35(4):408-15.

[4]. Dolmans DH, De Grave W, Wolfhagen IH, van der Vleuten CP. Problem-based learning: future challenges for educational practice and research. Medical education. 2005;39(7):732-41.

1 https://sbfis.org.br/pagina/graduacao 
[5]. Faria MJSSd, Nunes EdFPdA, Anastasiou L, Sakai MH, Silva VLMd. Os desafios da educação permanente: a experiência do curso de Medicina da Universidade Estadual de Londrina. Revista Brasileira de Educação Médica. 2008;32:248-53.

[6]. Francischetti I, Vieira C, Abdel Massih Pio D, Soares M, Colela A, Nunes C, et al. Active Learning Methodologies: An Experience for Faculty Training at Medical Education. Creative Education. 2014;05:1882-6.

[7]. Alves CL, Belisario SA, Abreu DM, Lemos JM, D'Avila LS, Goulart LM. Curricular transformations in medical school: an exploration of the promotion of change in Brazil. Medical education. 2013;47(6):617-26.

[8]. Bestetti RB, Couto LB, Romao GS, Araujo GT, Restini CB. Contextual considerations in implementing problem-based learning approaches in a Brazilian medical curriculum: the UNAERP experience. Medical education online. 2014;19:24366.

[9]. Treviso P, Costa BEPd. The perception of professionals from the health area regarding their training as lecturers. Texto \& Contexto - Enfermagem. 2017;26.

[10]. Abraham RR, Vinod P, Kamath MG, Asha K, Ramnarayan K. Learning approaches of undergraduate medical students to physiology in a non-PBL- and partially PBL-oriented curriculum. Advances in Physiology Education. 2008;32(1):35-7.

[11]. Abdul-Ghaffar TA, Lukowiak K, Nayar U. Challenges of teaching physiology in a PBL school. The American journal of physiology. 1999;277(6 Pt 2):S140-7.

[12]. Farmer EA. Faculty development for problem-based learning. European journal of dental education : official journal of the Association for Dental Education in Europe. 2004;8(2):59-66.

[13]. Steinert Y. Faculty development: from workshops to communities of practice. Medical teacher. 2010;32(5):425-8.

[14]. Baroffio A, Nendaz MR, Perrier A, Layat C, Vermeulen B, Vu NV. Effect of teaching context and tutor workshop on tutorial skills. Medical teacher. 2006;28(4):e112-9.

[15]. Dalrymple KR, Wuenschell C, Rosenblum A, Paine M, Crowe D, von Bergmann HC, et al. PBL core skills faculty development workshop 1: An experiential exercise with the PBL process. Journal of dental education. 2007;71(2):249-59.

[16]. Vogt K, Pelz J, Stroux A. Refinement of a training concept for tutors in problem-based learning. GMS J Med Educ. 2017;34(4):Doc38-Doc.

[17]. Almeida MTC, Maia FA, Batista NA. Gestão nas escolas médicas e sustentabilidade dos programas de desenvolvimento docente. Avaliação: Revista da Avaliação da Educação Superior (Campinas). 2013;18:299-310.

[18]. Oliveira GAd, Ferreira MBC, Nunes LN, Ribeiro MFM. Pedagogical training profile of basic health sciences faculty in biomedical and related fields at Brazilian public and private higher education institutions. Advances in Physiology Education. 2019;43(2):180-90.

[19]. Amaral E, Campos HH, Friedman S, Morahan PS, Araujo MN, Carvalho PM, et al. An educational international partnership responding to local needs: process evaluation of the Brazil FAIMER Regional Institute. Education for health (Abingdon, England). 2012;25(2):116-23.

[20]. Associação Brasileira de Educação Médica, ed. Cadernos da Abem. FAIMER Brasil 10 anos. Rio de Janeiro: ABEM, 2016.

[21]. Marcondes FK, Cardozo LT, Luchi KCG, Irfannuddin M, Karatzaferi C, Rocha MJ, et al. Meeting report: IUPS and ADInstruments 2017 Teaching Workshop. Advances in Physiology Education. 2018;42(2):334-9.

[22]. Mello-Carpes PB, Carpes FP. Improving physiology learning and understanding by adding outreach activities to the teaching: report of the IUPS and ADInstruments Teaching Workshop 2017. Advances in Physiology Education. 2018;42(1):159-61.

\section{Acknowledgments}


The authors thank all the participants of the workshops, as well as Dr. Fernanda $\mathrm{K}$. Marcondes and Dr. Luis Henrique Montrezor, who coordinated the IV Brazilian Physiology Teaching Workshop and agreed to develop a workshop about PBL during our meeting. 